\title{
The Effect of Massage toDecrease Lactic Acid Levels after Anaerobic Physical Activity
}

\author{
Rima Mediyana Sari ${ }^{1}$, Novita Sari Harahap ${ }^{2}$, Nurhamida Sari Siregar ${ }^{3}$, Marsal Rispandi ${ }^{4}$ \\ \{novitahrp74@gmail.com ${ }^{2}$ \} \\ Department of Sports Sciences,Universitas Negeri Medan, Medan, Indonesia ${ }^{1,2,3,4}$
}

\begin{abstract}
Anaerobic physical activity is a high physical activity because the muscles contract in anaerobic conditions. The energy used by ATP through the process of anaerobic glycolysis tends to produce more lactic acid.This, study aims to determine the effect of massage in reducing lactic acid levels after anaerobic exercise. Research on experimental studies using the Experimental Pre and Post- test design.Student subjects, male, aged 19-20 years, amounted to 16 people, divided into 2 groups, anaerobic exercise group without massage and a anaerobic group treat with combine massage. Examination of lactic acid is carried out after anaerobic physical activity which is 200 m run. Data were analyzed statistically using t test. We found that lactic acid levels after anaerobic physical activity were lower in the combination massage anaerobic exercise group than the non-massage anaerobic exercise group. Massage can reduce lactic acid levels after anaerobic physical activity.
\end{abstract}

Keywords: Anaerobic exercise, massage, lactic acid.

\section{Introduction}

Physical exercise is a body movement that is carried out in a planned and repetitive manner that causes an increase in energy use with the aim of improving physical fitness. Anaerobic physical exercise is a high intensity activity that requires energy quickly in a short time, but cannot be carried out continuously for a long time.

Anaerobic exercise is classified as a high intensity physical exercise so the muscles contract in anaerobic conditions so that the supply of ATP is through the process of anaerobic glycolysis. As a result, muscle glycogen during anaerobic physical exercise is reduced, while blood lactic acid levels increase, increased levels of lactic acid can interfere with performance (Powers, 2001; Powers 2008).

Lactic acid levels that accumulate, cause decreased ability of muscle contraction, performance and accelerate fatigue. Continued fatigue will result in pain with symptoms such as muscle spasms, swelling and decreased muscle strength which can affect performance (Chung et al., 2003). Recovery byeliminating accumulating lactic acid must be immediate because of crucial factors to improve athlete performance (Pinar et al. 2012).

Improved performance can be described by decreasing or rapid travel distance of $200 \mathrm{~m}$ runners. The recovery process in the muscles can be done by improving the microcirculation so that the elimination of lactic acid will increase. Massage is a method that can eliminate lactic acid from tissues by improving microcirculation, so that lactic acid can diffuse out of the 
muscle and enter the blood (Mika et al. 2007). This study aims to determine the effect of massage on decreased lactic acid runner $200 \mathrm{~m}$.

\section{Methods}

\subsection{Subjects}

The subjects were 16 people, male sex, age 20-22 years old, had a good VO 2 max level, no smoker, did not consume supplements and antioxidants 2 weeks before and during the study.

\subsection{Research Design}

This study used an Experimental Pre and Post-test design. The study was conducted at the UNIMED Faculty of Sport Science and Physical Physiology Laboratory. Research subjects were 16 people, divided into 2 groups randomly, namely group 1 (AN-SM) : anaerobic physical exercise without massage; group $2(\mathrm{AN}+\mathrm{SM})$ : anaerobic physical exercise and massage. Anaerobic physical exercise was done for 3 weeks, frequency 3 times a week. Massage on the right and left lower limbs is given after anaerobic exercise, for 12 minutes. In the pre-test and post-test each group measured lactic acid levels and runner travel time is $200 \mathrm{~m}$.

\subsection{Statistical Analysis}

Data were analyzed with statistics and presented in form of means and standard deviation, tables and figures. Each data obtained is first determined by the distribution of the Normality test.If the data is normally distributed, an independent $\mathrm{t}$ test is performed.

\subsection{Measurement of Lactic Acid Levels}

The research tools used were accutrend lactate and lactic acid strips, lotions and stopwatches. Blood lactic acid levels measured using accutrend lactate, 10 minutes after running 200meters, were stated in millimoles per liter $(\mathrm{mmol} / \mathrm{L})$.

\subsection{Data Analysis}

Data analysis with normality test and test with a significance level of $\mathrm{p}<0.05$ and $95 \%$ confidence level $(\alpha=0.05)$.

\section{Results}

Data were analyzed first by normality test, it was found that the data of lactic acid levels were normally distributed ( $\mathrm{p}<0.05$ ), as listed in table 1 . Table 2 , showed that the difference in mean lactic acid levels after anaerobic physical exercise in each group was smaller than before anaerobic physical exercise, namely the AN-SM group $(10.81 \pm 1.99$ vs. $10.19 \pm 1.37$; $\mathrm{p}=$ $0.343)$ and $\mathrm{AN}+\mathrm{SM}$ group $(13.97 \pm 1.85$ vs $11.35 \pm 2.17$; $\mathrm{p}=0.003)$. The results of the $\mathrm{t}-$ paired test showed that there was a significant treatment effect on the decrease in lactic acid 
levels in the anaerobic physical exercise group with massage $(A N+S M)$. Figure 1 shows that the mean level of lactic acid after anaerobic physical exercise in the AN + SM group was lower than in the AN-SM group. Based on independent $t$ test, it was found that there was a significant difference of $\mathrm{p}=0.000$, to a decrease in lactic acid levels.

Table 1.Normality test of the lactic acid

\begin{tabular}{lccc}
\hline \multirow{2}{*}{ Parameter } & \multirow{2}{*}{ Groups } & \multicolumn{2}{c}{ Normality test } \\
\cline { 3 - 4 } & & statistic & $\mathrm{p}$ \\
\hline Lactic acid & Pre test & 0.194 & $0.110^{*}$ \\
& Post test & 0.137 & $0.200^{*}$ \\
\hline
\end{tabular}

Note: $*$ signifikan $(\mathrm{p}>0,05), \mathrm{SD}:$ standard deviation

Table 2.Means of lactic acid

\begin{tabular}{|c|c|c|c|}
\hline \multirow[b]{2}{*}{ Variable } & \multicolumn{2}{|l|}{ Mean \pm SD } & \multirow[b]{2}{*}{ p-value } \\
\hline & $\begin{array}{l}\text { Group } \\
\text { AN-SM }\end{array}$ & $\begin{array}{l}\text { Group } \\
\text { AN+SM }\end{array}$ & \\
\hline \multicolumn{4}{|l|}{$\begin{array}{l}\text { Lactic } \\
\text { acid }\end{array}$} \\
\hline Pre-test & $10.81 \pm 1.99$ & $13.97 \pm 1.85$ & 0.055 \\
\hline Post-test & $10.19 \pm 1.37$ & $11.35 \pm 2.17$ & 0.000 \\
\hline t- paired & 0.343 & 0.003 & \\
\hline
\end{tabular}

Note: signifikan $(\mathrm{p}<0,05)$

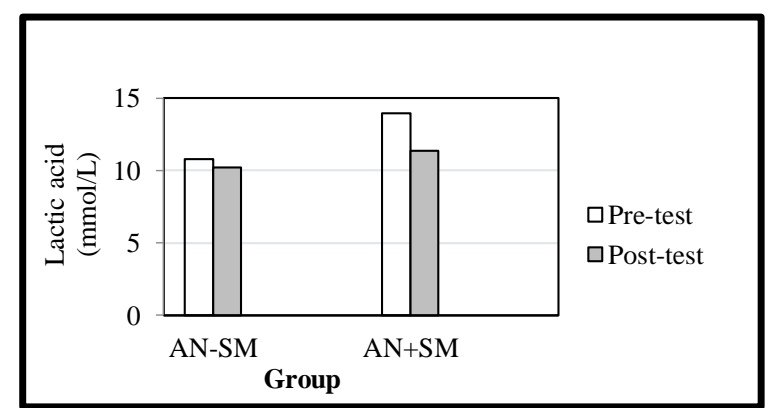

Figure 1.Average levels of lactic acid after anaerobic physical exercise in the AN-SM group and AN + SM groupgroup 


\section{Discussion}

The results of this study found that lactic acid levels after running $200 \mathrm{~m}$ were lower in the anaerobic physical exercise group given massage after each exercise in the legs compared to the group without massage. The results of this study are in line with the research of Harahap et al. (2018) which states that combination weight training with massage is better to reduce lactic acid levels compared to non-massage weight training on runners.

Massage is a mechanical manipulation of soft body parts with rhythmic pressure in order to produce physiological effects and can calm and reduce psychological stress by increasing endogenous morphine hormones such as endorphins, enkephalin and dinorphine while reducing stress levels of hormones such as the hormones cortisol, norepinephrine and dopamine (Best et al, 2008). Massage is an engineering recovery effort that activates the activation of venous pump and lymph pump mechanisms artificially, the purpose of which is to accelerate circulation. Recovery is the recovery of normal homeostasis conditions, which are the best physiological conditions for body cells (Giriwijoyo and Sidik, 2012).

Massage is physical manipulation consisting of body rubbing (effleurage), squeezing (petrissage), scouring (friction) in soft tissues throughout the body, which is carried out on the face, body, upper and lower limbs (Salvano, 1999). Physiological benefits for eliminating lactic acid have been widely used by athletes both to support physical performance and for other purposes such as prevention, therapy and rehabilitation of injuries and the negative effects of exercise (Wiltshire, 2009).

Lactic acid is the result of metabolism of glucose through the reaction of lactaside anaerobic glycolysis. Lactic acid produced from the reduction of pyruvic acid occurs in muscle tissue that lacks oxygen or hyposia, for example when exercising with relatively heavy intensity (Guyton \& Hall, 2008). Lactic acid builds up in the muscles due to hypoxic muscle tissue (Farenia et al, 2010).

In hypoxia there is an increase in the process of cell respiration because Adenosine Triphospat (ATP) decreases and the number of free radicals formed increases. In mitochondrial hypoxia is more susceptible, it cannot maintain the Krebs cycle and the oxidative phosphorylation process. The respiratory chain in the mitochondrial membrane will also be damaged, so that ATP is not produced. Energy sources during anaerobic physical exercise or during sprints are only obtained from the metabolism of anaerobic glycolysis. The metabolism of anaerobic glycolysis results in very fast lactate accumulation and can disrupt the physical condition (Rosidi et al., 2013).

Anaerobic physical exercise is classified as high intensity exercise so that high amounts of lactic acid will be produced. Increased levels of high lactic acid occur during exercise. Furthermore, lactic acid in the muscle dissociates into $\mathrm{H}^{+}$ions and lactate ions. Increased $\mathrm{H}^{+}$ ions cause a decrease in $\mathrm{pH}$ in extra and intracellular fluids. This decrease in $\mathrm{pH}$ will inhibit the binding of oxygen by Hemoglobin in the lungs, and can inhibit the activity of the enzyme phosphofructokinase and the myofibril ATP-ase enzyme in the muscles that play a role in ATP synthesis, so that the supply of energy becomes disrupted. Disruption of the supply of energy will reduce the ability of muscle contraction. (Wittenberg, 2003; Foss, 2006; Guyton \& Hall, 2008; Farenia et al, 2010).

The study conducted by Bahartresna (2005) on untrained individuals concluded that sports massage during recovery reduced blood lactic acid levels better than passive rest after 200 meters of running activity. Similarly, research conducted by Jones and Mondero proved that sports massage can increase the elimination of lactic acid during recovery after high intensity exercise. Similarly, the results of David's research, et al. sports massage for 20 
minutes causes a decrease in blood lactic acid by $36,21 \%$, and according to David et al. Sport massage for 45 minutes causes a decrease in blood lactic acid by $72.4 \%$ (David et al, 2005).

\section{Conclusions}

The conclusion of this study is that Massage given after anaerobic physical exercise has an effect on decreasing lactic acid levels after $200 \mathrm{~m}$ run.

Acknowledgements.We are gratefully to Ministry of Research and Technology and Higher Education Republic of Indonesia under the research grant UNIMED of Year 2018 with the Research Contract Number: 027/UN33.8/ LL /2018.

\section{References}

[1]Bahartresna,DA.: Perbandingan Efek Pemulihan Aktif, Massage dan Pemulihan Pasif terhadap Penurunan Kadar Laktat Darah. Tesis. Program Pascasarjana Universitas Padjadjaran.Bandung (2005) [2]Best, T.M., Hunter, R., Wilcox, A., Haq, F.: Critical Review : Effectiveness of Sport Massage for Recovery of Skeletal Muscle From Strenuous Exercise. Clinic Journal Sport Medicine.Vol 18, No 5, pp 446-460 (2008)

[3]David, Cotterrel, Jones, G.E.: Lactate clearance after combining exercise and massage following a bout of maksimum intensity cycling exercise. J Physiol 565P (2005)

[4]Farenia R, LesmanaR, Purba A, Akbar B, Shahib N, Koibuchi N, Shimokawa N.: Perbandinganantara Kadar serum MioglobinDenganLaktatSetelahAktifitasFisikAerobikdanAnaerobikPadaTikusWistar.BagianIlmuFaal FakultasKedokteranUniveritasPadjajaran,Bandung (2013

[5]Foss, M.L and Keteyian, S.J.: Physiological Basis for Exercise and Sport, Mc.Graw- Hill Companies. New York. 2006;59-64 (2006)

[6]Giriwijoyo, S., Sidik, D.Z.: IlmuFaalOlahraga (FisiologiOlahraga). PT RemajaRosdakarya.Juli 2012: 108 (2012)

[7]Guyton \& Hall.: Textbook of Medical Physiology 11th edition. Elsevier Saunders, Philadelphia, Pensylvania ;79-82;530;1056-6 (2008)

[8]Harahap, NS.: The Effect Of Regular Exercise And Sport Massage On Musculoskeletal Pain In Runner. International Journal of Advanced Research; 5(12) : 1479-1482 (2017)

[9]Mika, A., Mika, P.,Fernhall, B.: Comparison of Recovery Strategis on Muscle Performance AfterFatiquing Exercise. Am.J.Phy.Med.Rehabil; 86 : 474-481(2007)

[10]Chung JH, Lester RL, Dickson RC.: Sphingolipid requirement for generation of a functional v1 component of the vacuolar ATPase. J BiolChem 278(31):28872-81 (2013)

[11]Pinar,S., Kaya,F., Bicer, B., Erzeybek, M.S., Cotuk, H.B.: Different Recovery Methods And Muscle Performance After Exhausting Exercise : Comparison of The Effects of Electrical Muscle Stimulation And Massage. Biol Sport, Vol. 29 No 4, p 269-275 (2012)

[12]Powers, S.K, Howley, E.T.: Exercise Physiology. In : Theory and Application to Fitness and Performance. Ed 4. New York :McGraw Hill Company (2001)

[13]Powers S K and Jackson M J.: Exercise Induced Oxidative Stress: Cellular Mechanisms and Impact on Muscle Fore Production Journal Physiol 88 1243-1276 (2008)

[14]Rosidi, A., Setiawan, B., Riyadi,H., Briawan, D.: Efikasipemberianekstraktemulawakdan multivitamin mineral terhadappenurunankadarasamlaktatdarahatlet, Indonesian journal of micronutrient, vol.5, no.1 (2013) 
[15]Salvano, G. Susan.: Massage Therapy ; Principle \& Practice. WB.Saunders Co. Phyladelpia (1999)

[16]Wiltshire, E.V., Poitras, V., Pak, M., Honng, T., Rayner,J., and Tschakovsky, M.E.: Massage Impairs Postexercise Muscle Blood Flow and "Lactic Acid" Removal(2009)

[17]Wittenberg, JB, Wittenberg, BA.: Myoglobin function reassessed. J ExpBiol, 206: 201120(2003) 